\title{
Outlier Stands of Quaking Aspen in the Davis Mountains of West Texas: Clone or Clones?
}

\author{
Jerritt Nunneley¹, 0. W. Van Auken², John Karges ${ }^{3}$ \\ ${ }^{1}$ Virology and Immunology, Texas Biomedical Research Institute, San Antonio, USA \\ ${ }^{2}$ Department of Biology, University of Texas at San Antonio, San Antonio, USA \\ ${ }^{3}$ The Nature Conservancy, San Antonio, USA \\ Email: jwnaggie@yahoo.com, Oscar.Vanauken@utsa.edu, jkarges@tnc.org
}

Received 6 May 2014; revised 6 June 2014; accepted 24 June 2014

Copyright (C) 2014 by authors and Scientific Research Publishing Inc.

This work is licensed under the Creative Commons Attribution International License (CC BY). http://creativecommons.org/licenses/by/4.0/

(C) (j) Open Access

\begin{abstract}
Populus tremuloides (quaking aspen) is found from the Pacific to the Atlantic Ocean in the northern United States and Canada, and at higher elevations in the western United States and northern Mexico. While $P$. tremuloides can reproduce sexually or asexually, it is primarily a clonal species in the intermountain west, reproducing vegetatively via root sprouts, yielding genetically identical stems or ramets. In west Texas, isolated, outlier stands occur in the Guadalupe, Davis, and Chisos Mountains at an elevation of approximately $2300 \mathrm{~m}$. This study utilized seven microsatellites or simple sequence repeats (SSRs) to examine leaf samples from 10 widely separated stems in 10 isolated $P$. tremuloides individual stands within the Davis Mountains to determine the level of clonal and genetic diversity. We then examined differentiation among stands. Each stem sampled within a stand was genetically identical to all stems examined in that stand or was part of a clone. There were eight genetically identical clones from these ten stands, with three stands being genetically identical or part of the same clone. Many of the genotypes shared several of the same alleles and the remaining alleles were only a few base pairs apart. Some of these alleles have been previously identified in other western North American P. tremuloides stands. Microsatellites identified several triploid patterns consistent with possible aneuploidy, which is concurrent with previous studies.
\end{abstract}

Keywords

Populus tremuloides, Genetic Diversity, PCR, SSRs, Conservation

\section{Introduction}

Although Populus tremuloides (quaking aspen) is one of the most widespread trees in North America, it may

How to cite this paper: Nunneley, J., Van Auken, O.W. and Karges, J. (2014) Outlier Stands of Quaking Aspen in the Davis Mountains of West Texas: Clone or Clones? American Journal of Plant Sciences, 5, 2298-2311.

http://dx.doi.org/10.4236/ajps.2014.515244 
have been more common in the low elevations and southern areas some 15 to 20 thousand years ago at the end of the Pleistocene [1]-[4]. As the climate warmed, $P$. tremuloides is thought to have migrated north in range and to higher elevations. Isolated "mountain islands" of aspen have recently been described in western Texas [5] [6]. Could all of the isolated, present day stands of $P$. tremuloides in the Davis Mountains have been part of a mega population, which are now disconnected [7] [8]? The central and southern Rocky Mountains of North America are thought to have large clones of $P$. tremuloides that provide evidence supporting the theory that western portions of the USA may hold ancient clones reproducing vegetatively, that may have been present 15,000 - 20,000 years ago [8]-[11]. Unfortunately, this remains unproven because too few studies have been conducted concerning clonal fragmentation on a large landscape-scale.

Studies of $P$. tremuloides in the Cascades and Sierra Nevada Mountains demonstrated that smaller stands tend to be single clones while larger populations consist of a mosaic of multiple genotypes or clones [12] [13]. Intermountain west populations appear to be primarily large with multiple clones [14]. Populations in northeastern North America near the Great Lakes [15] and as far as Quebec consist of smaller stands with multiple clones [11] [16] [17].

A considerable amount is known about the biology and ecology of $P$. tremuloides, for example it is an early successional species, and it forms clones with shallow and fairly widespread roots with considerable vegetative sprouting [18] [19]. Fire seems to play an important role in the regeneration of $P$. tremuloides communities [6] since it is a successional species and as a result its presence in a given physical area will increase and decrease through time. Fires were fairly frequent in the Davis Mountains from approximately 1772 until about 1926 [20].

The $P$. tremuloides stands in the Davis Mountains are found on steep, talus slopes or outcrops and most probably did not burn in the past. Populus tremuloides communities, in general, are not susceptible to fire since fires burn out relatively quickly after entering a high density Populus community, or the fire may even burn around them [21]-[24]. The way that fire promotes regeneration of these $P$. tremuloides communities is during the later stage of community replacement by spruce, fir or other conifers. It is then that the P. tremuloides community is fire-prone. Fires will burn through the coniferous- $P$. tremuloides community, kill the evergreens, and topkill P. tremuloides. Populus tremuloides will root-sprout and hundreds of thousands of juveniles per hectare will regenerate and cover the burned area [25].

After an extended period without fire, light levels at the soil surface of these forest communities can be reduced by the canopy such that seedlings and saplings of shade-intolerant species such as $P$. tremuloides are growth-suppressed [26]. This is a natural process and constantly occurring in various North American P. tremuloides communities. Without fire or other disturbance, species that are more shade-tolerant, such as members of the genera Acer, Betula, Quercus and Tsuga, establish and then increase in basal area [27].

Although light levels were reduced under existing $P$. tremuloides canopies in the Davis Mountains when we examined them, regeneration was still occurring. There was a high density of $P$. tremuloides juveniles under the canopy, especially in the younger stands [6]. This provided some indication that light level may not be the only factor limiting recruitment into the adult population in these relatively small and open stands. It has been hypothesized that the spatial distribution and relative size of aspen clones is also directly related to inter- and intraspecific competitive interactions, age, as well as biotic and abiotic habitat factors [17] [18] [28].

However, genetic relationships among individuals of these small, isolated west Texas stands remain unknown. Unfortunately, clonal boundaries cannot always be delineated solely based on morphological traits of the plant [16] [29]. Therefore, microsatellites or simple-sequence repeats (SSRs) have been used to demonstrate genetic relationships in various species and populations including P. tremuloides [30]. Since they appear to be selectively neutral, this makes microsatellites good candidate markers for comparative genetic studies [13] [31]. They have been commonly used in population genetics as well as forensic analysis [32] [33] and provide the exact length of the fragment in base pairs starting with the 5' labeled primer [34]. Molecular markers are useful particularly in $P$. tremuloides as they have a high rate of heterozygosity and are often triploid at some loci [35]. To our knowledge, there are no published papers describing the clonal or genetic structure of these known outlier $P$. tremuloides stands in the Davis Mountains of west Texas. We hypothesized that all of the isolated P. tremuloides stands in the Davis Mountains of west Texas were a single identical clone. In the present study, all known isolated stands of $P$. tremuloides from the Davis Mountains were studied using seven microsatellites. The objectives of this study were to demonstrate relationships between individuals of each of the $P$. tremuloides stands and among all known isolated stands in the Davis Mountains. 


\section{Materials and Methods}

\subsection{Study Area}

The study area was in the Davis Mountains of west Texas (Figure 1(a), from [36]). Ten P. tremuloides stands were sampled from locations on northern and northeastern talus slopes (avg. slope $=29.8^{\circ}$ ) on Mount Livermore, nearby Pine Peak, and in Cherry Canyon (Figure 1(b), from [37]). Ecological data was previously collected from these $P$. tremuloides stands [6] and is summarized here (Table 1). Actual or estimated $P$. tremuloides relative tree density was $27 \%$ - $92 \%$ (low in a few cases because of other species), relative basal area was $48 \%$ - $96 \%$ (4.1 to $23.0 \mathrm{~m}^{2} / \mathrm{ha}$ ) and juvenile density was $32-14,000$ stems/ha (Table 1). Populus tremuloides stand ages were estimated to be between 35 - 77 years based on tree-ring measurements (in 2013) which were significantly linearly related $\left(\mathrm{y}=1.66 \mathrm{x}+9.79, r^{2}=0.90, P<0.0001\right)$. In addition, $P$. tremuloides community age was inversely related to the $I n$ of the total $P$. tremuloides density and mean basal area was significantly linearly and positively related to age, or older communities had fewer but larger $P$. tremuloides stems or trees.

\subsection{Sample Collection}

Leaf samples were collected from apparently mature $P$. tremuloides trees in each stand in October of 2012 and May of 2013. Ten representative trees throughout each of the ten stands were haphazardly sampled. Five leaves

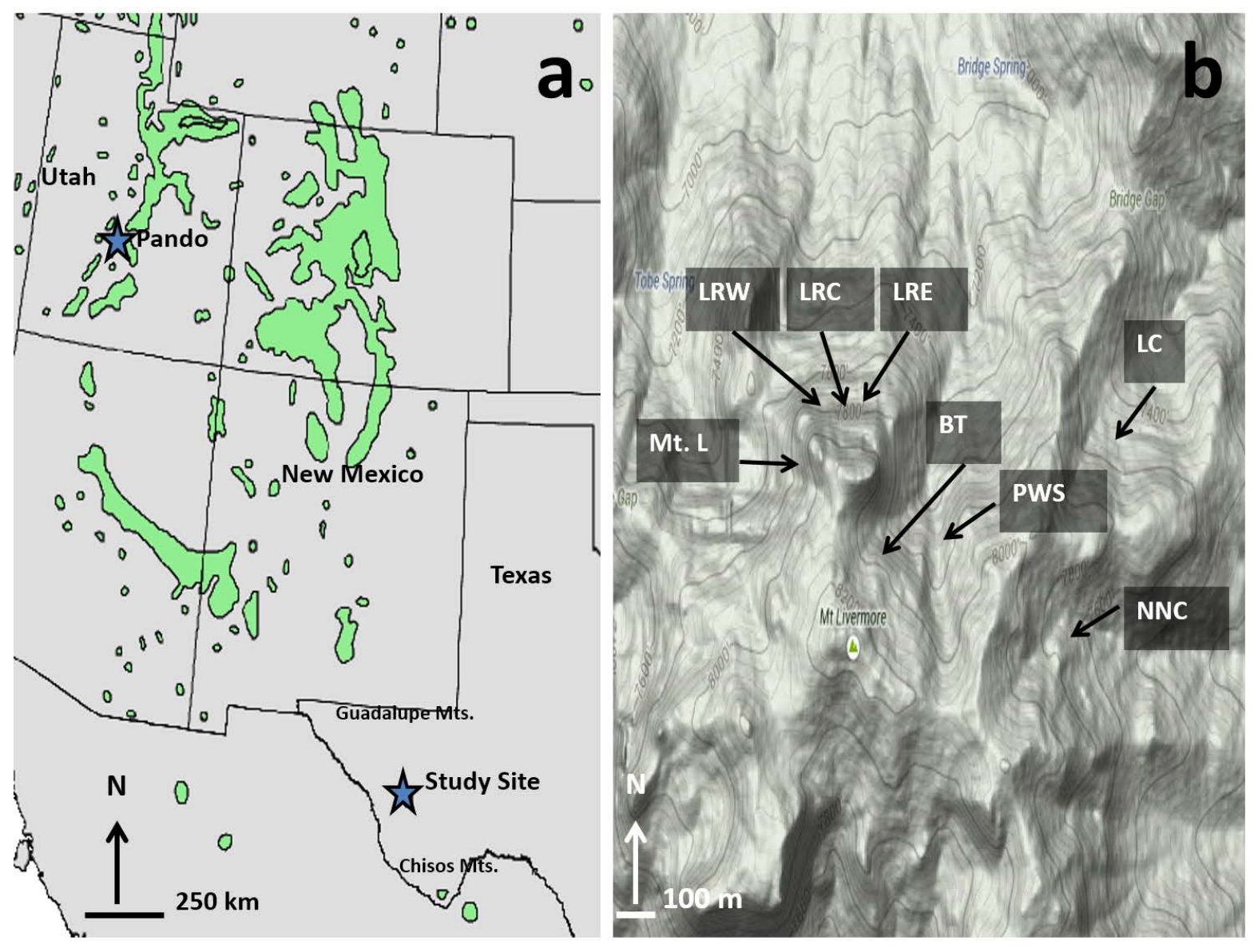

Figure 1. (a) Map of the southwestern United States and northern Mexico with dark grey areas indicating Populus tremuloides communities and stars identifying the study site in the nature conservancy's Davis Mountains Preserve of west Texas and the "Pando" population of central Utah (from [1] [36]). The approximate locations of the Guadalupe Mountains and Chisos Mountains of west Texas are also shown; (b) Locations of eight of the isolated Populus tremuloides stands around Mt. Livermore in the Davis Mountains are shown (from [37]). The Pine Peak stand is $6.25 \mathrm{~km}$ northeast and Cherry Canyon is 30.0 km northeast of Mt. Livermore. Abbreviations: Mt. L: Mt. Livermore North, LRW: Laura’s Rock West, LRC: Laura’s Rock Central, LRE: Laura’s Rock East, BT: Big Tree, PWS: Peewee Springs, LC: Limpia Chute, and NNC: No Name Canyon. 
were removed from each of the ten selected P. tremuloides trees (Figure 2). An eastern cottonwood (Populusdeltoides Marsh.) from northwest Bexar County Texas was used as a genetic outlier (same genus but different species). Four samples from the Utah "Pando" and nearby populations (kindly supplied by Dr. Valerie Hipkins, USDA Forest Service, Placerville, Calif.) were used as positive controls. Leaves from each sampled tree were placed in separate plastic bags containing enough silica gel to cover the leaves ( $200 \mathrm{~g})$. Silica gel was used to remove moisture from the leaves drying and preserving them until weighing and extraction [30].

\subsection{DNA Extraction}

Twenty milligrams of dry leaf tissue was removed from the leaf (not the petiole), weighed, cut up, and placed in a microfuge tube containing a $7 \mathrm{~mm}$ Qiagen ${ }^{\circledR}$ stainless steel bead and buffer [30]. A Qiagen ${ }^{\circledR}$ TissueLyser was used to homogenize the samples at $30 \mathrm{~Hz}$ for $2.5 \mathrm{~min}$, flipped, and repeated once more. Total genomic DNA was isolated per the manufacturer's instructions using a Qiagen ${ }^{\circledR}$ DNEasy plant mini kit for dry tissue extraction.

\subsection{Microsatellite Analysis}

Samples were genotyped at seven microsatellite loci: WPMS 14, WPMS 15, and WPMS 20 [38] and PMGC 433, PMGC 576, PMGC 2571, and GCPM 970-1 (http://www.ornl.gov/sci/ipgc/ssr_resource.htm). The $25.0 \mu \mathrm{L}$ total reaction volume contained $10 \mathrm{ng}$ template DNA, $1 \times$ reaction buffer, $1.8-2.0 \mathrm{mM} \mathrm{MgCl}$, $200-250 \mu \mathrm{M}$ each dNTP, $0.25-0.40 \mu \mathrm{M}$ each of the forward and reverse primers, and $0.2-0.3$ units Hot Star Taq polymerase. Reactions were carried out as follows: 4 cycles at $94^{\circ} \mathrm{C}(30 \mathrm{~s}), 55^{\circ} \mathrm{C}(30 \mathrm{~s}), 72^{\circ} \mathrm{C}(1 \mathrm{~min}) ; 4$ cycles of $94^{\circ} \mathrm{C}(30 \mathrm{~s})$, $52^{\circ} \mathrm{C}(30 \mathrm{~s}), 72^{\circ} \mathrm{C}(1 \mathrm{~min}) ; 25$ cycles of $94^{\circ} \mathrm{C}(30 \mathrm{~s}), 50^{\circ} \mathrm{C}(30 \mathrm{~s}), 72^{\circ} \mathrm{C}(1 \mathrm{~min})$; with a final extension of $72^{\circ} \mathrm{C}$ for $15 \mathrm{~min}$ [30]. The annealing temperature was raised to $58^{\circ} \mathrm{C}$ for the first 4 cycles for PMGC-2571, WPMS-14, WPMS-15, and WPMS-20. Amplicons were visualized on a 1.5\% agarose electrophoresis gel (Figure 3). Since we could not fully resolve amplicons that were only a few base pairs apart, all samples were further analyzed by capillary electrophoresis (Figure 4). The 5' end of the forward primer for each locus was fluorescently labeled for automated analysis [38] using an ABI-3130xl Genetic Analyzer. Amplicons were submitted to The University of Texas Health Science Center at San Antonio (UTHSCSA) NAC core facility for capillary electrophoresis.

\subsection{Data Analysis}

Populus tremuloides microsatellite fragment sizes were scored in the programs Genemapper (v4.1, Applied

Table 1. Biotic and abiotic characteristics of the P. tremuloides communities studied in the Davis Mountains of west Texas. Included are estimated stand age (from 2013), $P$. tremuloides tree density (\%), $P$. tremuloides juvenile density (stems/ha), $P$. tremuloides tree basal area (\%), elevation, latitude, and longitude (modified from [6]).

\begin{tabular}{|c|c|c|c|c|c|c|c|}
\hline Stand & Age (yrs) & $\begin{array}{l}\text { Aspen tree } \\
\text { density (\%) }\end{array}$ & $\begin{array}{c}\text { Aspen } \\
\text { juvenile } \\
\text { density }\end{array}$ & $\begin{array}{c}\text { Aspen } \\
\text { basal area } \\
(\%)\end{array}$ & Elevation (m) & Latitude & Longitude \\
\hline Mt. Livermore North & $75^{* *}$ & 43 & 60 & 94 & 2368 & $30^{\circ} 38^{\prime} 14.22^{\prime \prime N}$ & $104^{\circ} 10^{\prime} 17.26^{\prime \prime W}$ \\
\hline Laura's Rock West & $74^{* *}$ & 43 & 55 & 89 & 2352 & $30^{\circ} 38^{\prime} 23.11^{\prime \prime N}$ & $104^{\circ} 10^{\prime} 32.18^{\prime \prime W}$ \\
\hline Laura’s Rock Central & 71 & 43 & 32 & 95 & 2379 & $30^{\circ} 38^{\prime} 21.76^{\prime \prime} \mathrm{N}$ & $104^{\circ} 10^{\prime} 23.41^{\prime \prime W}$ \\
\hline Laura's Rock East & 77 & 39 & 96 & 92 & 2373 & $30^{\circ} 38^{\prime} 22.46^{\prime \prime N}$ & $104^{\circ} 10^{\prime} 20.77^{\prime \prime W}$ \\
\hline Big Tree & 76 & 27 & 816 & 58 & 2368 & $30^{\circ} 38^{\prime} 21.67 " \mathrm{~N}$ & $104^{\circ} 10^{\prime} 17.26^{\prime \prime} \mathrm{W}$ \\
\hline Peewee Springs & $54^{* *}$ & 40 & 1,000 & 57 & 2362 & $30^{\circ} 38^{\prime} 12.12^{\prime \prime} \mathrm{N}$ & $104^{\circ} 10^{\prime} 11.64^{\prime \prime W}$ \\
\hline No Name Canyon & 50 & 72 & 14,000 & 93 & 2369 & $30^{\circ} 38^{\prime} 36.00^{\prime \prime N}$ & $104^{\circ} 9^{\prime} 52.28^{\prime \prime} \mathrm{W}$ \\
\hline Limpia Chute & 37 & 36 & 1,248 & 48 & 2315 & $30^{\circ} 38^{\prime} 18.28^{\prime \prime N}$ & $104^{\circ} 9^{\prime} 47.41^{\prime \prime W}$ \\
\hline Pine Peak & 38 & 92 & 4,048 & 56 & 2332 & $30^{\circ} 39^{\prime} 20.42 " \mathrm{~N}$ & $104^{\circ} 6^{\prime} 49.93^{\prime \prime W}$ \\
\hline Cherry Canyon & $* * *$ & $* * *$ & $* * *$ & $* * *$ & 1948 & $30^{\circ} 52 ' 28.34 " \mathrm{~N}$ & $104^{\circ} 1$ '35.92"W \\
\hline
\end{tabular}

${ }^{*}$ Stems/ha. ${ }^{* *}$ Estimated. ${ }^{* * *}$ Unknown. 


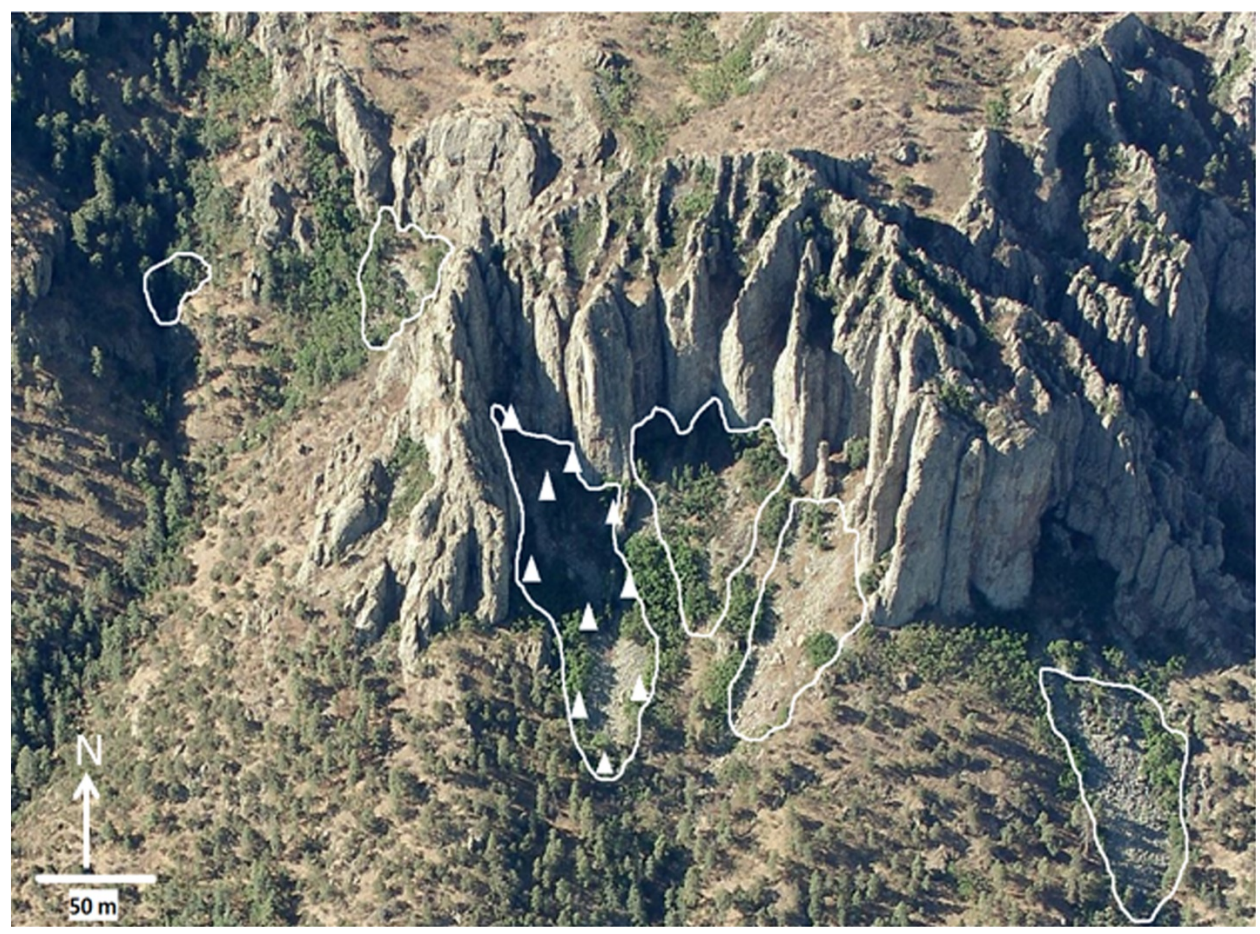

Figure 2. Six of the ten $P$. tremuloides stands in this study are shown and delineated in white. The stands are named left to right: Peewee Springs, Big Tree, Laura’s Rock East, Laura’s Rock Central, Laura’s Rock West, and Mt. Livermore North. White triangles indicate approximate locations of sampled trees within the Laura's Rock East stand.

\section{Lane Identification}

1. Big Tree 1

2. Big Tree 2

3. Peewee Springs 1

4. Peewee Springs 2

5. Limpia Chute 1

6. Limpia Chute 2

7. Limpia Chute 3

8. Limpia Chute 4

9. Pando $(+)$ CNTL

10. $\mathrm{H}_{2} \mathrm{O}(-) \mathrm{CNTL}$

11. Empty Lane

12.100 bp Standard
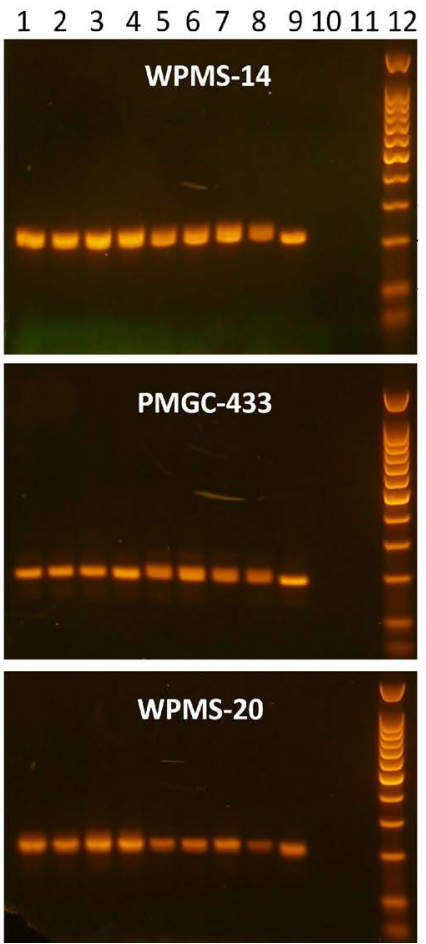
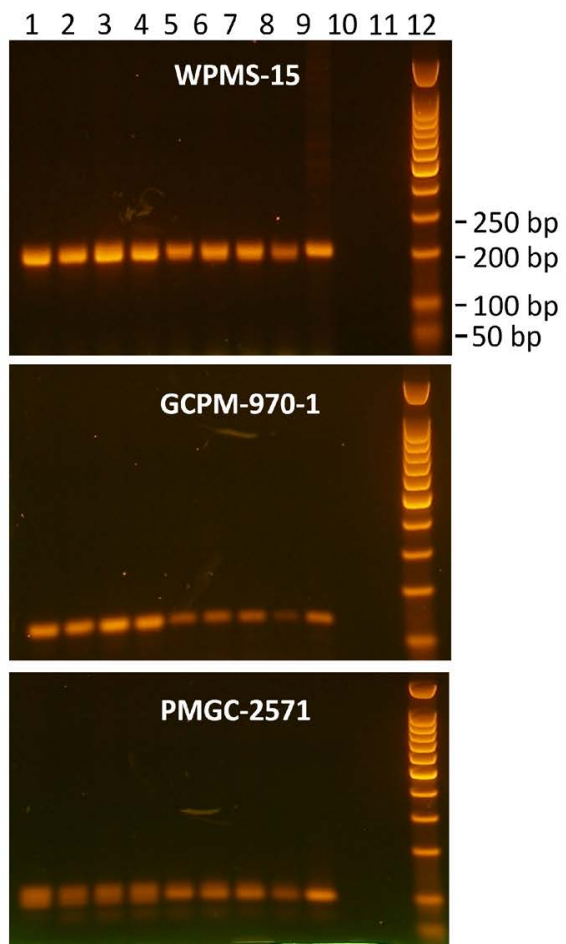

Figure 3. Example of PCR products from several of the stands visualized by $1.5 \%$ electrophoresis agarose gels for microsatellites WPMS-14, WPMS-15, PMGC-433, GCPM-970-1, WPMS-20, and PMGC-2571. See the top of the figure for lane number and lane identifications are on the left. Numbers next to arrows indicate the number of bp's (base pairs) of the standard in lane 12. 


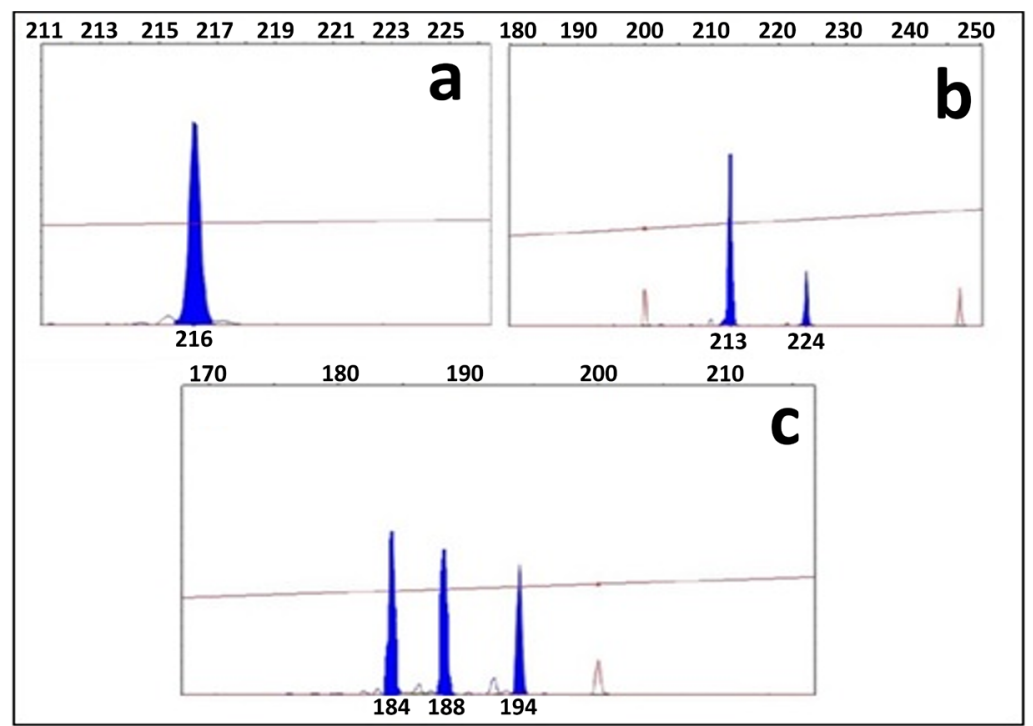

Figure 4. Example of capillary electrophoresis sequencing chromatographs for three microsatellites from the Limpia Chute population of Populus tremuloides. From top left (a) WPMS-14; (b) WPMS-20; and (c) PMGC-433. Red peaks are the ROX500 standard, blue peaks are sample, the $\mathrm{x}$-axis indicates increasing number of base pairs from left to right, and the $y$-axis is relative absorbance. WPMS-20 produced a single peak at $216 \mathrm{bp}$, WPMS-14 produced two peaks at 213 and 224 bp, and PMGC-433 exhibited three peaks at 184, 188, and 194 bp indicating homozygote, heterozygote and triploid alleles respectively.

Biosystems, Inc.) and Peak Scanner (v1.0, Life Technologies, Inc.) with verification by visual inspection of the raw data. The probability of identity $\operatorname{Pr}(i)$ or the probability that any of two of the observed genotypes are identical by chance was estimated over the seven loci for each of the stands using GenAlEx v.6 thereby quantifying an average specific multilocus genotype probability randomly generated from the stands, such that for the alleles $i$ and $j$ with frequencies $p_{i}$ and $p_{j}, \operatorname{Pr}(i)=\sum p_{i}+\sum \sum\left(2 p_{i} p_{j}\right)$, for all $i \neq j \quad$ [39] [40].

The Davis Mountain $P$. tremuloides stands were compared to the "Pando" and adjacent populations from Utah by an Analysis of Molecular Variance (AMOVA) in order to estimate genetic variation among regional populations. An allelic distance matrix was used as input for the AMOVA. As simple step-wise mutation rarely holds true in natural populations, $F$-statistics $\left(F_{S T}\right)$ for codominant data were calculated using GENALEX v6.0 (Peakall and Smouse 2005). Phylogenetic trees were constructed using the PHYLIP v3.69, [41] software package. Allele frequencies were first calculated using the frequency function in GenAlEx and were then used to create an infile to run a bootstrap of 1000 replicates in PHYLIP's Seqboot function. The function Genedist was used applying Nei's genetic distance [42] under the assumption of genetic drift and a rate of neutral mutation of alleles. Finally, the functions Neighbor for UPMGA method of clustering, Consense to obtain bootstrap values, and Drawtree to plot an unrooted tree diagram were employed.

\section{Results}

A total of 100 Populus tremuloides trees from the Davis Mountains were assayed. All 10 leaf samples from each stand yielded identical alleles at each of the seven loci. However, only the Laura's Rock stand has been shown (Table 2). The total number of alleles observed for each microsatellite in the Davis Mountain P. tremuloides stands varied from 4 - 13, there were five triploids and the observed allelic ranges for all seven microsatellites depended on the locus (Table 3). Eight unique genotypes were identified from the ten P. tremuloides stands sampled in the Davis Mountains. All samples within each stand had the same alleles and thus the same genotype indicating that each stand is a clone.

The microsatellite products for WPMS-15, WPMS-20, and GCPM-970-1 appear to yield single bands for most of the reactions while WPMS-14, PMGC-433, and PMGC-2571 show three bands for most of the reactions 
(Table 4). The three Laura's Rock P. tremuloides stands had identical peaks for each microsatellite, thus theywere a single clone (Table 4). These three Laura's Rock P. tremuloides stands found across the northern exposure of Laura's Rock (Laura's Rock West, Central, and East, Figure 2) had the same genotype. Positive controls 18-B, 22-B, 24-B, and 264-B from the Utah "Pando" and nearby populations of $P$. tremuloides confirmed previously published genotypes. Multilocus genotypes displayed high levels of heterozygosity and allelic variation, with most alleles being shared with the Utah samples. The single specimen of $P$. deltoides displayed unique alleles at WPMS-14, WPMS-20, PMGC-433, PMGC-576, and GCPM-970-1 loci (Table 4). The probability of identity was estimated to assess the likelihood that matching genotypes arose by chance and not clonal reproduction. For the seven loci, the probability of identities ranged from $1 \times 10^{-3}$ to $7.5 \times 10^{-3}$, indicating matching genotypes are likely due to vegetative reproduction. The AMOVA indicated Utah and Texas P. tremuloides populations to be moderately differentiated, with $4 \%$ of the estimated molecular variance held among populations and 96\% held within individual populations $(P=0.062)$.

A phylogenetic tree comparing all of the Davis Mountain P. tremuloides stands was completed (Figure 5(a)). Bootstrap values ranged from $13 \%$ - 100\% out of 1000 replicates. Samples with values of $70 \%$ or higher were considered significantly related. Because most bootstrap values were not significant, any number of similar trees could be drawn. Populus deltoides proved an appropriate out group for these analyses (Figure 5(a)).

Table 2. Allele size in base pairs for all microsatellite alleles for all 10 leaf samples of the Laura's Rock Central (LRC) Populus tremuloides stand. All alleles are identical for each sample thus one single homozygotic genotype is present in this $P$. tremuloides stand.

\begin{tabular}{cccccccc}
\hline \multirow{2}{*}{ Sample ID } & \multicolumn{7}{c}{ Microsatellites } \\
\cline { 2 - 7 } & WPMS-14 & WPMS-15 & WPMS-20 & PMGC-433 & PMGC-576 & PMGC-2571 & GCPM-970-1 \\
\hline 1 & $209 / 221$ & 193 & 216 & $180 / 184$ & $156 / 166$ & 100 & 122 \\
2 & $209 / 221$ & 193 & 216 & $180 / 184$ & $156 / 166$ & 100 & 122 \\
3 & $209 / 221$ & 193 & 216 & $180 / 184$ & $156 / 166$ & 100 & 122 \\
4 & $209 / 221$ & 193 & 216 & $180 / 184$ & $156 / 166$ & 100 & 122 \\
5 & $209 / 221$ & 193 & 216 & $180 / 184$ & $156 / 166$ & 100 & 122 \\
6 & $209 / 221$ & 193 & 216 & $180 / 184$ & $156 / 166$ & 100 & 122 \\
7 & $209 / 221$ & 193 & 216 & $180 / 184$ & $156 / 166$ & 100 & 122 \\
9 & $209 / 221$ & 193 & 216 & $180 / 184$ & $156 / 166$ & 100 & 122 \\
10 & $209 / 221$ & 193 & 216 & $180 / 184$ & $156 / 166$ & 100 & 122 \\
\hline
\end{tabular}

Table 3. Allelic ranges in base pairs, number of alleles observed, and number of triploids seen for each of the seven microsatellites examined from all Populus tremuloides stands in the Davis Mountains of west Texas.

\begin{tabular}{cccc}
\hline Locus & Allelic range (bp) & No. of alleles & No. of triploids \\
\hline PMGC-2571 & $78-114$ & 13 & 5 \\
WPMS-14 & $200-259$ & 12 & 5 \\
PMGC-433 & $180-208$ & 9 & 1 \\
GCPM-970-1 & $118-133$ & 8 & 1 \\
PMGC-576 & $149-180$ & 6 & 2 \\
WPMS-20 & $204-224$ & 4 & 1 \\
\hline
\end{tabular}


Table 4. Multilocus genotypes observed in all Populus tremuloides stands from the Davis Mountains of Texas. Site abbreviations follow Table 1; CW = Populus deltoides. Samples having one allele are homozygotes, those having two alleles are heterozygote, and those with three are putatively triploid.

\begin{tabular}{cccccccc}
\hline & & & & Microsatellites & & \\
Site & WPMS-14 & WPMS-15 & WPMS-20 & PMGC-433 & PMGC-576 & PMGC-2571 & GCPM-970-1 \\
\hline Mt. L & $212 / 215$ & 184 & $204 / 212$ & $180 / 184 / 186$ & $166 / 168$ & $92 / 98$ & $122 / 125$ \\
LRE & $209 / 221$ & 193 & 216 & $180 / 184$ & $156 / 166$ & 100 & 122 \\
LRC & $209 / 221$ & 193 & 216 & $180 / 184$ & $156 / 166$ & 100 & 122 \\
LRW & $209 / 221$ & 193 & 216 & $180 / 184$ & $156 / 166$ & 100 & 122 \\
PP & 206 & 184 & $212 / 216$ & $180 / 192$ & 166 & $96 / 101 / 112$ & 122 \\
LC & $212 / 224$ & $184 / 193 / 196$ & 216 & $184 / 188 / 194$ & $166 / 168$ & $90 / 94 / 96$ & 122 \\
NNC & $209 / 212$ & $184 / 193$ & 212 & 184 & $156 / 162$ & $90 / 92 / 94$ & $119 / 122$ \\
BT & $212 / 221$ & $184 / 193$ & $212 / 216 / 218$ & $180 / 184 / 186$ & $162 / 170$ & $90 / 96 / 102$ & $119 / 122$ \\
PWS & $213 / 221 / 224$ & $184 / 193$ & $212 / 216 / 218$ & $180 / 184 / 186$ & $162 / 170$ & $90 / 98 / 102$ & $119 / 122$ \\
CC & $203 / 221 / 230$ & $196 / 199$ & 218 & $180 / 190 / 194$ & $162 / 166 / 168$ & 98 & $119 / 122 / 125$ \\
18-B & $206 / 230$ & $184 / 196$ & $216 / 224$ & $186 / 196$ & $156 / 168$ & $98 / 114$ & 122 \\
22-B & $206 / 212$ & 184 & $212 / 222$ & $186 / 196$ & $156 / 168$ & $100 / 114$ & 122 \\
24-B & $200 / 203 / 212$ & $184 / 193$ & 216 & $182 / 186$ & $156 / 168$ & $88 / 98$ & $119 / 122$ \\
264-B & 230 & $184 / 193$ & $204 / 216$ & $182 / 196$ & $156 / 162$ & $98 / 102$ & $119 / 122$ \\
CW & $253 / 259$ & 196 & 221 & $200 / 208$ & $149 / 180$ & $78 / 96$ & $128 / 134$ \\
\hline
\end{tabular}

* Outgroup.

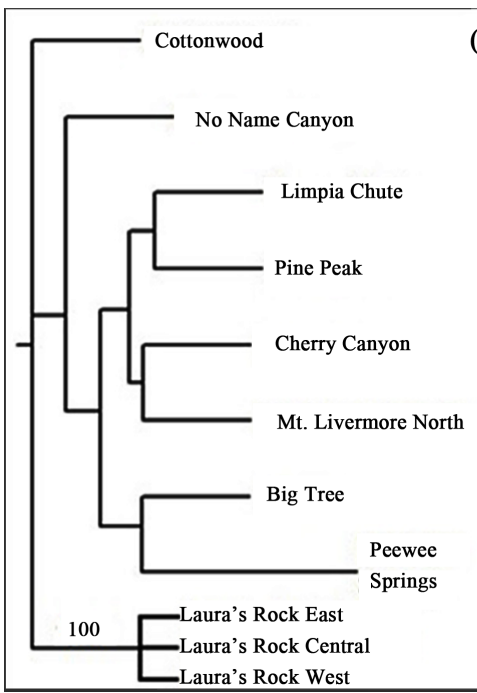

(a)

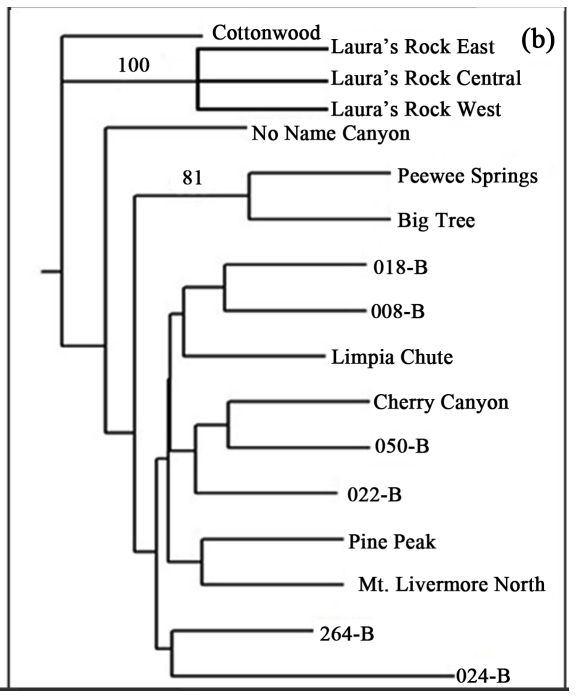

Figure 5. Unrooted Neighbor-joining phenograms constructed from allele frequencies. Bootstrap values are confidence values ranging from 1 to $100 \%$ with values greater than $70 \%$ indicating significant support for the proposed branching. (a) The Davis Mountain Populus tremuloides stands and Populus deltoides (cottonwood) as an outlier. Only the Laura's Rock stands' bootstrap value was significant and shown as $100 \%$. All other stand percentages ranged from $1 \%-31 \%$ indicating no significant genetic difference in the alleles of these stands and are not listed. (b) Davis Mountain (named) and Utah (numbered) Populus tremuloides stands including Populus deltoides (cottonwood as an outlier). Bootstrap values ranged from 9\% - 100\% with only the Laura’s Rock (100\%) and Peewee Springs and Big Tree (81\%) stands showing significant support for proposed branching. All other stands show less than significant allelic differences. 
A second phylogenetic tree compared both the Davis Mountain and Utah P. tremuloides samples (Figure 5(b)). Bootstrap values ranged from 9\% - 100\%. The "Big Tree" and "Peewee Springs" P. tremuloides stands were again grouped together; however this grouping was significant at $81 \%$. Interestingly, the Utah samples were more closely related to multiple Davis Mountain samples rather than themselves. Given that most of the bootstrap values for both trees in Figure 5 were not significant; this indicates that the stands in the Davis Mountains are closely related to one another and that they share many common alleles with the Utah populations.

\section{Discussion}

Although Populus tremuloides is one of the most widespread species of woody plant in North America today [1], it probably had a more restricted range when North America was covered with ice at various times in the past [43] [44]. Deglaciation during the Holocene has caused major fluctuations in extent and composition of plant communities throughout the world [45]-[50].

Populus tremuloides stands in the Davis Mountains and in other areas of west Texas could have established as clones early in the Holocene. However, we have no evidence to support that supposition. It is unclear if these early Davis Mountain stands of $P$. tremuloides were first established sexually via long-distance wind dispersal of viable seeds from large genetic neighborhoods [11] [51] or by cross-pollination and seed dispersal of local stands already present or previously established within the Davis Mountains. Observation of the flowering of the stands currently in the Davis Mountains should indicate which stands are male or female since this is unknown at this time [52]. This could help to identify the initial seed source of some or all of these stands. Sexual reproduction is very important for maintaining a rich gene pool and preventing genetic drift, although seedling establishment of $P$. tremuloides in the intermountain west is thought to be rare due to a narrow set of germination requirements for this species [11] [53]-[55].

Our study of the P. tremuloides stands in the Davis Mountains tested the hypothesis that all stands arose from a single large clone. Multilocus microsatellite genotypes indicated that all 10 stands sampled were individual clones (but three were identical). These 10 stands of $P$. tremuloides occurred on north or northeast facing talus slopes typically against a rock outcrop and were considerably smaller compared to known intermountain west populations [14] [18] [30] [56]. Stand area in the current study ranged from $238 \mathrm{~m}^{2}$ (Pine Peak) to 10,641 $\mathrm{m}^{2}$ (Laura's Rock East). Areas were estimated using satellite maps combined with actual photographs and tree density was not homogenous throughout each stand. Because of the relatively small size of the stands and haphazard sampling throughout each stand, we were confident that they were not a patch work of multiple genotypes and that all stand boundaries were sampled with no missed adjacent genotypes. Though much larger, the "Pando" clone was also found to be distinct within its boundaries, lacking any other genotypes within the matrix, although 40 different genotypes were observed adjacent to the giant clone [30]. The identical clone observed in the three Laura's Rock stands further confirms that molecular markers are an effective tool to determine clonal boundaries and their relative size.

Genotypes were different among all but 3 of the P. tremuloides stands in the Davis Mountains. We found that each of the 10 samples for each of the stands of Laura's Rock (east, central, and west) were identical for all loci (Table 4). Because these 3 stands have identical peaks and a number of alleles at each locus, we assigned them the same genotype. Here, a unique genotype was defined as a difference of one base pair in an allele between two populations. However, we think that these three, fragmented stands were at one time part of a larger population that stretched continuously across the face of Laura's Rock. In addition, we did not compare the entire genome. However, plans are underway to sequence several samples from each stand for total genome comparison.

Eight genetically distinct $P$. tremuloides clones on talus slopes were identified in the Davis Mountains (Table 3 ). We suspect that there were times in the past that sexual reproduction of the $P$. tremuloides stands in this area occurred and seeds from various populations reached sites suitable for plant establishment in the Davis Mountains. However, we cannot offer a date. We suggest that it was a wetter time and after one or more relatively large scale disturbances such as fire or drought, seedling establishment occurred. How many clones were established at this time is also unknown. At least eight clones that established sometime in the past have survived until today and many probably perished. If all of the surviving clones established at the same time is also unknown. However, large numbers of seedlings were reported after fires in Yellowstone and Grand Teton National Parks [57] with most of these seedlings established on moist soil or in wet sites. Moist soil or wet soil sites are gener- 
ally not available most of any given year in the Davis Mountains. In the Davis Mountains in the past, seedlings probably established lower in elevation compared to where they are found today. They probably established in the same drainages on wet soil, and then migrated up in elevation to new, wet areas as the climate warmed and dried until they reached the upper part of the drainage or slope which they currently occupy.

We do not believe that the eight clones identified in the Davis Mountains in west Texas are the result of the accumulation of somatic mutations of the SSR regions of the genome as suggested by others for old established clones [16] [57]. There are few differences in base pairs between the separate clonal genotypes (Table 3). We do not see how genetic homogenization of a genet could occur after a somatic mutation happened and then have the somatic mutation be carried to other stems via the roots of one tree when the distance of root growth would be hundreds of meters to the next new stem. Accumulation of somatic mutations has been suggested but we think the chance of it happening would be remote, even given a very long time (thousands of years). Multiple mutations occur in somatic cells, but if they occurred in leaf tissue, they would be lost each year with leaf fall. We found no issues with potential scoring errors in our data set [58] [59] such as stuttering, large allele dropout or null alleles since all samples within each stand were identical.

We found that many of the alleles were shared throughout the stands. Alleles that differed only did so by a few base pairs (Table 3). This is an indication that these stands are closely related and that some of these alleles are conserved. In addition, previously published alleles [30] were observed along with numerous novel alleles. Given that our study site was far removed from the "Pando" population, novel alleles were expected. In the future it should be possible to examine the entire genetic makeup of all or at least many of the different stems of the stands that we now consider clones. However, to date, this has not been done for any P. tremuloides stand [30] [35].

Most organisms cannot survive with more than two copies of an allele; however, P. tremuloides may and in doing so greatly increases the genetic diversity within the species [10] [11] [16] [35] [59]-[61]. There are several plausible explanations for why three alleles have been observed. Individual clones may be triploid, have extra copies of an individual chromosome (aneuploidy), or have a fragment of a chromosome duplicated in its genome [62]. Any of these events may lead to the observation of three alleles if the microsatellite locus of interest occurred in a duplicated region. At least one triploid was seen for each locus in the Davis Mountain P. tremuloides samples with the most for any locus being five (Table 3 and Table 4). Curiously, only one triploid was seen for all loci in the Utah samples and none for $P$. deltoids in the current study. However, extensive studies of the "Pando" population and other areas of Utah [14] [30] have led to the identification of large triploid stands that likely have reduced fertility [63] but that are vegetatively more vigorous.

\section{Conclusion}

The stature and composition of these isolated Davis Mountains $P$. tremuloides stands has changed over recent years and will continue to change in the future since $P$. tremuloides is a successional species [6]. Prediction of changes will be difficult and concerns for the decline of $P$. tremuloides stands, including those in the Davis Mountains, do exist and are not new [6] [64]-[71]. As surface light levels decline with community development and succession, encroachment of lower light requiring species will occur and $P$. tremuloides stand size and the number of stands will decrease [6] [72] [73]. Various studies have shown divergent interpretations of aspen decline which seems to have temporal and spatial dependencies and to be cyclic [72]. The added pressures of increasing density of neighboring woody plants especially lower light requiring species, longer fire intervals, succession to conifers, and climate change will probably play a major role in the future of these $P$. tremuloides stands [6] [68] [71] [72] [74] [75]. Currently, these isolated P. tremuloides communities in the Davis Mountains are geographically positioned such that lateral expansion is their only option for movement as the climate changes in the future.

\section{Acknowledgements}

The authors greatly thank Jennifer DeWoody for her generous help and guidance with the data analysis and manuscript review. We also wish to thank Shawn Benedict and Greg Crow of The Nature Conservancy for facilitating access and accommodations. We thank Valerie Hipkins of the USDA Forest Service National Forest Genetics Laboratory for supplying DNA samples and protocols, and Ricardo Carrion Jr. and Jean L. Patterson of Texas Biomedical Research Institute for equipment use and donated supplies. Thanks to David D. Senseman and 
Hans Heidner, Department of Biology at The University of Texas at San Antonio for manuscript review. Funding for this research came from the Department of Biology at The University of Texas at San Antonio, the US Forest Service, and the Texas Academy of Science.

\section{References}

[1] Little, E.L. (1971) Atlas of United States Tress. Vol. 1. Conifers and Important Hardwoods. USDA, Forest Service, Washington DC.

[2] Benson, L., Burdett, J., Lund, S., Kashgarian, M. and Mensing, S. (1997) Nearly Synchronous Climate Change in the Northern Hemisphere during the Last Glacial Termination. Nature Letters, 388, 263-265. http://dx.doi.org/10.1038/40838

[3] Moore, G.W.K., Holdsworth, G. and Alverson, K. (2002) Climate Change in the North Pacific Region over the Past Three Centuries. Nature Letters, 420, 401-403. http://dx.doi.org/10.1038/nature01229

[4] Jomelli, V., et al. (2011) Irregular Tropical Glacier Retreat over the Holocene Epoch Driven by Progressive Warming. Nature Letters, 474, 196-199. http://dx.doi.org/10.1038/nature10150

[5] Powell, A.M. (1998) Trees and Shrubs of the Trans-Pecos and Adjacent Areas. University of Texas Press, Austin.

[6] Van Auken, O.W., Bush, J.K., Richter, F.A. and Karges, J. (2007) Structure of Isolated Populations of Populus tremuloides (Quaking Aspen) in the Davis Mountains of Far-West Texas. Natural Areas Journal, 27, 302-312. http://dx.doi.org/10.3375/0885-8608(2007)27[302:SOIPOP]2.0.CO;2

[7] Ally, D., Ritland, K. and Otto, S.P. (2008) Can Clone Size Serve as a Proxy for Clone Age? An Exploration Using Microsatellite Divergence in Populus tremuloides. Molecular Ecology, 22, 4897-4911. http://dx.doi.org/10.1111/j.1365-294X.2008.03962.x

[8] Barnes, B.V. (1975) Phenotypic Variation of Trembling Aspen in Western North America. Forest Science, 21, 319328.

[9] Kemperman, J.A. and Barnes, B.V. (1976) Clone Size in American Aspens. Canadian Journal of Botany, 54, 26032607. http://dx.doi.org/10.1139/b76-280

[10] Cheliak, W.M. and Dancik, B. (1982) Genetic Diversity of Natural Populations of a Clone Forming Tree Populus tremuloides. Canadian Journal of Genetics and Cytology, 24, 611-616.

[11] Jelinski, D.E. and Cheliak, W.M. (1992) Genetic Diversity and Spatial Subdivision of Populus tremuloides Salicaceae in a Heterogeneous Landscape. American Journal of Botany, 79, 728-736. http://dx.doi.org/10.2307/2444937

[12] Hipkins, V.D. and Kitzmiller, J.H. (2004) Genetic Variation and Clonal Distribution of Quaking Aspen in the Central Sierra Nevada. Transactions of the Western Section of the Wildlife Society, 40, 32-44.

[13] DeWoody, J., Rickman, T.H., Jones, B.E. and Hipkins, V.D. (2009) Allozyme and Microsatellite Data Reveal Small Clone Size and High Genetic Diversity in Aspen in the Southern Cascade Mountains. Forest Ecology and Management, 258, 687-696. http://dx.doi.org/10.1016/j.foreco.2009.05.006

[14] Mock, K.E., Rowe, C.A., Hooten, M.B., DeWoody, J. and Hipkins, V.D. (2008) Clonal Dynamics in Western North American Aspen (Populus tremuloides). Molecular Ecology, 17, 4827-4884. http://dx.doi.org/10.1111/j.1365-294X.2008.03963.x

[15] Cole, C.T. (2005) Allelic and Population Variation of Microsatellite Loci in Aspen (Populus tremuloides). New Phytologist, 167, 155-164. http://dx.doi.org/10.1111/j.1469-8137.2005.01423.x

[16] Wyman, J., Bruneau, A. and Tremblay, M.F. (2003) Microsatellite Analysis of Genetic Diversity in Four Populations of Populus tremuloides in Quebec. Canadian Journal of Botany, 81, 360-367. http://dx.doi.org/10.1139/b03-021

[17] Namroud, M.C., Park, A., Tremblay, F. and Bergeron, Y. (2005) Clonal and Spatial Genetic Structures of Aspen (Populus tremuloides Michx.). Molecular Ecology, 14, 2969-2980. http://dx.doi.org/10.1111/j.1365-294X.2005.02653.X

[18] Barnes, B.V. (1966) The Clonal Growth Habit of American Aspens. Ecology, 47, 439-447. http://dx.doi.org/10.2307/1932983

[19] Schier, G.A. (1973) Origin and Development of Aspen Root Suckers. Canadian Journal of Forest Research, 3, 45-53. http://dx.doi.org/10.1139/x73-007

[20] Camp, A., Poulos, H.M., Gatewood, R., Sirotnak, J. and Karges, J. (2006) Assessment of Top down and Bottom up Controls on Fire and Vegetation Abundance and Distribution Patterns in the Chihuahuan Desert Borderlands: A Hierarchical Approach. Unpublished Final Report to the Joint Fire Sciences Program, Project No. 03-3-3-13. Yale University, US National Park Service and The Nature Conservancy, 77 p.

[21] Fechner, G.H. and Barrows, J.S. (1976) Aspen Stands as Wildfire Fuel Breaks. Eisenhower Consortium Bulletin 4, USDA, Forest Service, Rocky Mountain Forest and Range Experiment Station, Fort Collins. 
[22] Bevins, C.D. (1984) Historical Fire Occurrence in Aspen Stands of the Intermountain West. Cooperative Agreement 22-C-4-INT-31, Systems for Environmental Management, Missoula.

[23] Brown, J.K. and Simmerman, D.G. (1986) Appraisal of Fuels and Flammability in Western Aspen: A Prescribed Fire Guide. General Technical Report INT-205. USDA Forest Service, Intermountain Forest Experiment Station, Fort Collins.

[24] Rothwell, R.L., Woodard, P.M. and Samran, S. (1991) The Effect of Soil Water on Aspen Litter Moisture Content. In: Andrews, P.L. and Potts, D.F., Eds., Proceedings of the 11th Conference on Fire and Forest Meteorology, Bethesda, 117-123.

[25] Brinkman, K.A. and Roe, E.I. (1975) Quaking Aspen: Silvics and Management in the Lake States. Agriculture Handbook 486, USDA, Forest Service, Washington DC.

[26] Van Auken, O.W. and McKinley, D.C. (2008) Structure and Composition of Juniperus Communities and Factors That Control Them. In: Van Auken, O.W., Ed., Western North American Juniperus Communities: A Dynamic Vegetation Type, Springer, New York, 19-47. http://dx.doi.org/10.1007/978-0-387-34003-6_2

[27] Abrams, M.D. (2003) Where Has All the White Oak Gone? Bioscience, 53, 927-939.

[28] Romme, W.H., Turner, M.G., Tuskan, G.A. and Reed, R.A. (2005) Establishment, Persistence, and Growth of Aspen (Populus tremuloides) Seedlings in Yellowstone National Park. Ecology, 86, 404-418. http://dx.doi.org/10.1890/03-4093

[29] Ellstrand, N.C. and Roose, M.L. (1987) Patterns of Genotypic Diversity in Clonal Plant Species. American Journal of Botany, 74, 123-131. http://dx.doi.org/10.2307/2444338

[30] DeWoody, J., Rowe, C.A., Hipkins, V.D. and Mock, K.E. (2008) “Pando” Lives: Molecular Genetic Evidence of a Giant Aspen Clone in Central Utah. Western North American Naturalist, 68, 493-497. http://dx.doi.org/10.3398/1527-0904-68.4.493

[31] Van Oosterhout, C., Van Heuven, M.K. and Brakefield, P.M. (2004) On the Neutrality of Molecular Genetic Markers: Pedigree Analysis of Genetic Variation in Fragmented Populations. Molecular Ecology, 13, 1024-1034. http://dx.doi.org/10.1111/j.1365-294X.2004.02114.x

[32] Butler, J.M. (2006) Genetics and Genomics of Core Short Tandem Repeat Loci Used in Human Identity Testing. Journal of Forensic Science, 51, 253-265. http://dx.doi.org/10.1111/j.1556-4029.2006.00046.x

[33] Milde-Kellers, A., Krawczak, M., Augustin, C., Boomgaarden-Brandes, K., Simeoni, E., Kaatsch, H.J., et al. (2008) An Illicit Love Affair during the Third Reich: Who Is My Grandfather? Journal of Forensic Science, 53, $377-379$.

[34] Stepukhovich, A., Tsupryk, A., Kosobokova, O., Gavrilov, D.N., Gorbovitski, B., Gudkov, G., et al. (2008) Analysis of DNA Sequencing Systems Based on Capillary Electrophoresis. Technical Physics, 53, 763-775. http://dx.doi.org/10.1134/S1063784208060169

[35] Mock, K.E., Callahan, C.M., Islam-Faridi, M.N., Shaw, J.D., Rai, H.S., Sanderson, S.C., et al. (2012) Widespread Triploidy in Western North American Aspen (Populus tremuloides). PLoS ONE, 7, Article ID: e48406. http://dx.doi.org/10.1371/journal.pone.0048406

[36] Google Maps (2014) Mt. Livermore: Fort Davis, TX. https://www.google.com/maps/place/Mt+Livermore/@30.6354265,-104.1732454,1112m/data=!3m2!1e3!4b1!4m2!3m 1!1s0x86ef9b6b84c51603:0xda1ebd2c127ae88f

[37] Bing Maps (2014) Mt. Livermore: Fort Davis, TX. http://www.bing.com/maps/\#Y3A9MjkuNDAzNzAwfi05OC43MjQ2MDImbHZsPTQmc3R5PXImcT1NdC4lMjUyM ExpdmVybW9yZSUyNTIwdHg

[38] van der Schoot, J., Pospišková, M., Vosman, B. and Smulders, M.J.M. (2000) Development and Characterization of Microsatellite Markers in Black Poplar (Populus nigra L.). Theoretical and Applied Genetics, 101, 317-322. http://dx.doi.org/10.1007/s001220051485

[39] Peakall, R. and Smouse, P.E. (2005) GENALEX 6: Genetic Analysis in Excel. Population Genetic Software for Teaching and Research. Molecular Ecology Notes, 6, 288-295. http://dx.doi.org/10.1111/j.1471-8286.2005.01155.X

[40] Sherman, C.D.H. (2008) Mating System Variation in the Hermaphroditic Brooding Coral, Seriatopora hystrix. Heredity, 100, 296-303. http://dx.doi.org/10.1038/sj.hdy.6801076

[41] Felsenstein, J. (2005) PHYLIP (Phylogeny Inference Package) Version 3.6. Distributed by the Author. University of Washington, Seattle.

[42] Nei, M. (1972) Genetic Distance between Populations. The American Naturalist, 106, 283-392. http://dx.doi.org/10.1086/282771

[43] Imbrie, J. and Imbrie, K.P. (1979) Ice Ages: Solving the Mystery. Enslow, Short Hills.

[44] McClaran, M.P. and Van Devender, T.R. (1995) The Desert Grassland. University of Arizona Press, Tucson.

[45] Delcourt, P.A., Delcourt, H.R. and Webb, T. (1983) Dynamic Plant Ecology: The Spectrum of Vegetation Change in 
Space and Time. Quatinary Science Review, 1, 153-175.

[46] Betancourt, J.L., Van Devender, T.R. and Martin, P.S. (1990) Packrat Middens: The Last 40,000 Years of Biotic Change. University of Arizona Press, Tucson.

[47] Miller, R.F. and Wigand, P.E. (1994) Holocene Changes in Semiarid Pinyon-Juniper Woodlands: Response to Climate, Fire, and Human Activies in the US Great Basin. BioScience, 44, 465-474. http://dx.doi.org/10.2307/1312298

[48] Van Devender, T.R. (1995) Desert Grassland History: Changing Climates, Evolution, Biography, and Community Dynamics. In: McClaran, M.P. and Van Devender, T.R., Eds., The Desert Grassland, University of Arizona Press, Tucson, 68-99.

[49] Horne, F. and Kahn, A. (1997) Phylogeny of North American Wild Rice, a Theory. Southwestern Naturalist, 42, 423434.

[50] Robichaux, R.H. (1999) Ecology of the Sonoran Desert Plants and Plant Communities. University or Arizona Press, Tucson.

[51] Every, A.D. and Wiens, D. (1971) Triploidy in Utah Aspen. Madroño, 12, 138-147.

[52] Maini, J.S. (1972) Silvics and Ecology in Canada. In USDA, Forest Service General Technical Report NC-1, Washington DC, 67-73.

[53] Faust, M.E. (1936) Germination of Populus grandidentata and P. tremuloides with Particular Reference to Oxygen Consumption. Botanical Gazette, 97, 808-821. http://dx.doi.org/10.1086/334605

[54] Kay, C.E. (1993) Aspen Seedlings in Recently Burned Areas of Grand Teton and Yellowstone National Parks. Northwest Science, 67, 94-104.

[55] Romme, W.H., Turner, M.G., Gardner, R.H., Hargrove, W.W., Tuskan, G.A., Despain, D.G., et al. (1997) A Rare Episode of Sexual Reproduction in Aspen (Populus tremuloides Michx.) Following the 1988 Yellowstone Fires. Natural Areas Journal, 17, 17-25.

[56] Mitton, J.B. and Grant, M.C. (1996) Genetic Variation and the Natural History of Quaking Aspen. BioScience, 46, 2531.

[57] Tuskan, G.A., Francis, K.E., Russ, S.L., Romme, W.H. and Turner, M.G. (1996) RAPD Markers Reveal Diversity within and among Clonal and Seedling Stands of Aspen in Yellowstone National Park, USA. Canadian Journal of Forest Research, 26, 2088-2098. http://dx.doi.org/10.1139/x26-237

[58] DeWoody, J., Nason, J.D. and Hipkins, V.D. (2006) Mitigating Scoring Errors in Microsatellite Data from Wild Populations. Molecular Ecology Notes, 6, 651-957.

[59] Lund, S.T., Furnier, G.R. and Mohn, C.A. (1992) Isozyme Variation in Quaking Aspen in Minnesota. Canadian Journal of Forest Research, 22, 521-524. http://dx.doi.org/10.1139/x92-068

[60] Yeh, F.C., Chong, D.K.X. and Yang, R.C. (1995) RAPD Variation within and among Natural Populations of Trembling Aspen (Populus tremuloides Michx.) from Alberta. Journal of Heredity, 86, 454-460.

[61] Stevens, M.T., Turner, M.G., Tuskan, G.A., Romme, W.H., Gunter, L.E. and Waller, D.M. (1999) Genetic Variation in Postfire Aspen Seedlings in Yellowstone National Park. Molecular Ecology, 8, 1769-1780. http://dx.doi.org/10.1046/j.1365-294x.1999.00732.x

[62] Tuskan, G.A., Difazio, S., Jansson, S., Bohlmann, J., Grigoriev, I., Hellsten, U., et al. (2006) The Genome of Black Cottonwood, Populus trichocarpa (Torr. \& Gray). Science, 313, 1596-1604.

[63] Ramsey, J. and Schemske, D.W. (1998) Pathways, Mechanisms, and Rates of Polyploidy Formation in Flowering Plants. Annual Review of Ecology and Systematics, 29, 467-501. http://dx.doi.org/10.1146/annurev.ecolsys.29.1.467

[64] Baker, F.S. (1925) Aspen in the Central Rocky Mountain Region. USDA Bulletin No. 1291. USDA, Washington DC.

[65] Bartos, D.L. and Campbell, R.B. (1998) Decline of Quaking Aspen in the Interior West-Examples from Utah. Rangelands, 20, 17-24.

[66] Rogers, P. (2002) Using Forest Health Monitoring to Assess Aspen Forest Cover Change in the Southern Rockies Ecoregion. Forest Ecology and Management, 155, 223-236. http://dx.doi.org/10.1016/S0378-1127(01)00560-6

[67] Frey, B.R., Lieffers, V.J., Hogg, E.H. and Landhäusser, S.M. (2004) Predicting Landscape Patterns of Aspen Dieback: Mechanisms and Knowledge Gaps. Canadian Journal of Forest Research, 34, 1379-1390. http://dx.doi.org/10.1139/x04-062

[68] Hogg, E.H., Brandt, J.P. and Michaellian, M. (2008) Impacts of a Regional Drought on the Productivity, Dieback, and Biomass of Western Canadian Aspen Forests. Canadian Journal of Forest Research, 38, 1373-1384. http://dx.doi.org/10.1139/X08-001

[69] Worrall, J.J., Egelanda, L., Eagera, T., Maska, R.A., Johnsonb, E.W., Kemp, P.A., et al. (2008) Rapid Mortality of Populus tremuloides in Southwestern Colorado, USA. Forest Ecology and Management, 255, 686-696. 
http://dx.doi.org/10.1016/j.foreco.2007.09.071

[70] Worrall, J.J., Marchetti, S.B., Egeland, L., Mask, R.A., Eager, T. and Howell, B. (2010) Effects and Etiology of Sudden Aspen Decline in Southwestern Colorado, USA. Forest Ecology and Management, 260, 638-648. http://dx.doi.org/10.1016/j.foreco.2010.05.020

[71] Kulakowski, D., Matthews, C., Jarvis, D. and Veblen, T.T. (2013) Compounded Disturbances in Sub-Alpine Forests in Western Colorado Favor Future Dominance by Quaking Aspen (Populus tremuloides). Journal of Vegetation Science, 24, 168-176. http://dx.doi.org/10.1111/j.1654-1103.2012.01437.x

[72] Kashian, D.M., Romme, W.H. and Regan, C.M. (2007) Reconciling Divergent Interpretations of Quaking Aspen Decline on the Northern Colorado Front Range. Ecological Applications, 17, 1296-1311. http://dx.doi.org/10.1890/06-1431.1

[73] Smith, T.M. and Smith, R.L. (2012) Elements of Ecology. 8th Edition, Pearson Benjamin Cummings, San Francisco.

[74] Mueggler, W.F. (1985) Forage. In: DeByle, N.V. and Winokur, R.P., Eds., Aspen: Ecology and Management in the Western United States. USDA Forest Service, Rocky Mountain Research Station, Fort Collins, 129-134.

[75] Mueggler, W.F. (1989) Age Distribution and Reproduction of Intermountain Aspen Stands. Western Journal of Applied Forestry, 4, 41-45. 
Scientific Research Publishing (SCIRP) is one of the largest Open Access journal publishers. It is currently publishing more than 200 open access, online, peer-reviewed journals covering a wide range of academic disciplines. SCIRP serves the worldwide academic communities and contributes to the progress and application of science with its publication.

Other selected journals from SCIRP are listed as below. Submit your manuscript to us via either submit@scirp.org or Online Submission Portal.
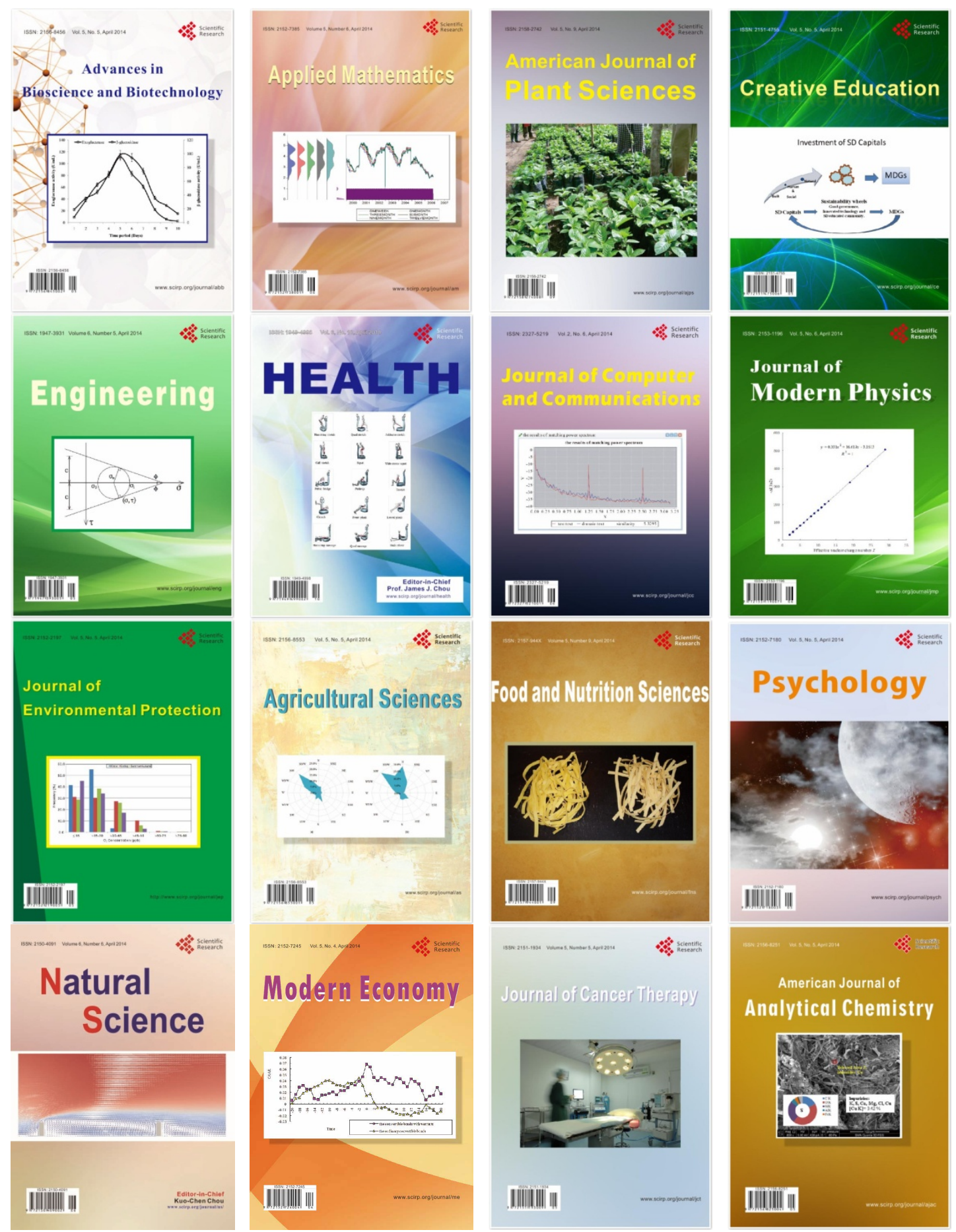